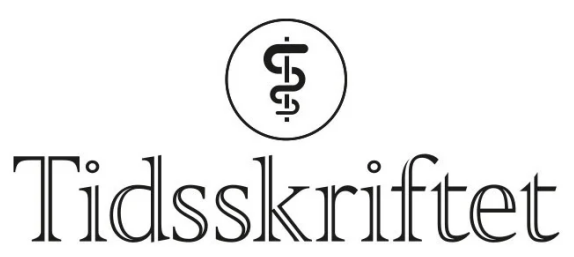

DEN NORSKE LEGEFORENING

\title{
Mentorgrupper i medisinutdanningen
}

LEGELIVET

CECILIE NORMANN BIRKELI

cecilie.normann@legeforeningen.no

LEFO - Legeforskningsinstituttet

\section{Mentorprogrammer der en gruppe studenter regelmessig kan møte en erfaren lege som mentor, har et stort potensial, viser en ny studie.}

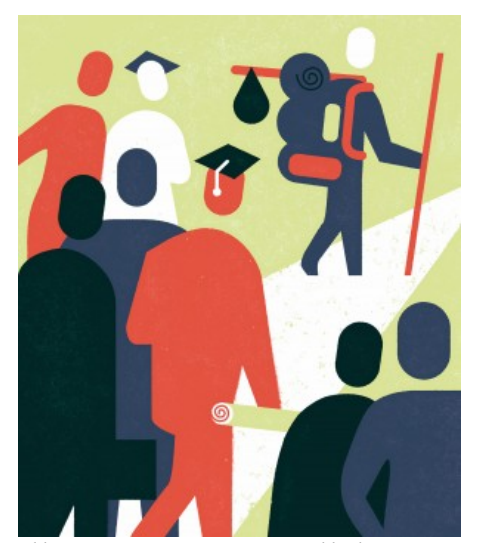

Illustrasjon: Aron Vellekoop León / NTB scanpix

Mentorprogrammer er en viktig ressurs for læring og profesjonell utvikling i medisinutdanningen i mange land, men det er stor variasjon i hvordan slike programmer organiseres, både innad i land og mellom land (1ㅣ). Den felles møteplattformen fremmer læring ved at studentene kan drøfte egne og medstudenters erfaringer og diskutere problemstillinger de møter i klinisk praksis og i studiehverdagen. Ved å samle medisinstudenter i grupper legges et grunnlag for diskusjon og tilbakemeldinger på egne og hverandres refleksjoner i et støttende miljø.

I Norge er det etablert formelle mentorgrupper for medisinstudenter ved Universitetet $\mathrm{i}$ Troms $\emptyset$ - Norges arktiske universitet fra 2012 og ved Universitetet i Bergen fra 2014. I Oslo har det i flere år vært en frivillig mentorordning organisert av medisinstudentene i samarbeid med Oslo legeforening (므). 
I en nylig publisert systematisk oversikt av Skjevik og medarbeidere ble målsetninger, organisering og evaluering av gruppementorprogrammer for medisinstudenter unders $ø \mathrm{kt}$. Av de 20 inkluderte studiene ble 17 ulike mentorprogrammer i syv land beskrevet. Selv om funnene viser store variasjoner i organisering og evaluering, viste de fleste studiene at det å delta i mentorgrupper hadde flere positive effekter og at dette var en nyttig læringsstrategi i medisinsk utdanning. Det gjenstår likevel mer forskning for å kunne sammenligne organisering og positive effekter, slik at resultatene i større grad blir overførbare til andre fakulteter.

«Mentorgrupper gir rom for meningsfulle samtaler og refleksjoner $i$

trygge omgivelser»

Til tross for at den vitenskapelige litteraturen på feltet er begrenset, viser oversikten at mentorgrupper har et stort potensial for medisinstudenter. De gir rom for meningsfulle samtaler og refleksjoner i trygge omgivelser, i en ellers hektisk og utfordrende studiehverdag. Basert på funnene i oversikten anbefaler forfatterne å optimalisere den positive effekten av mentorgrupper. Forfatterne fremhever blant annet at slike møter bør være obligatoriske og gjennomføres regelmessig. Dette vil både sikre studentoppmøte og signalisere at mentorgrupper er en viktig del av studiet.

\section{LITTERATUR}

1. Skjevik EP, Boudreau JD, Ringberg U et al. Group mentorship for undergraduate medical studentsa systematic review. Perspect Med Educ 2020; 9. doi: 10.1007/s40037-020-00610-3. [PubMed][CrossRef]

2. Gulbrandsen P. En mentor for medisinstudenten. Tidsskr Nor Legeforen 2015; 135: 1218. [PubMed] [CrossRef]

Publisert: 12. oktober 2020. Tidsskr Nor Legeforen. DOI:10.4045/tidsskr.20.0724

(C) Tidsskrift for Den norske legeforening 2023. Lastet ned fra tidsskriftet.no 26. april 2023. 